\title{
IMAGINARIOS SOCIALES EN TORNO A LOS ALMACENES DE BARRIO EN UNA CIUDAD MEDIA
}

\author{
María Inés Del Águila ${ }^{1}$
}

\section{Introducción}

Este trabajo se enmarca en una investigación que tiene por objetivo general indagar en los imaginarios sociales de una ciudad media de la Provincia de Buenos Aires, en torno a la noción nativa de almacén de barrio. Durante el proceso de investigación ${ }^{2}$ unas recurrencias en los sentidos asociados a los almacenes de barrio se impusieron como desafíos a problematizar etnográficamente. Estas recurrencias consistían en registros de expresiones referidas a aquellos, como prácticas comerciales que "ya no existen", o que "ya no existen, tal y como eran los almacenes de antes". El uso de "la libreta para el fiado", "las charlas interminables del almacenero", "la yapa", "el chusmerío del barrio" que se concentraba en el almacén de "don Julio" o "la María". Éstas prácticas, entre otras, eran referidas como parte del pasado y al mismo tiempo como constituyendo la "esencia", del "típico almacén de barrio". Incluso con un desfasaje temporo-espacial, registré asociaciones de los almacenes de barrio, con "los almacenes de ramos generales" rurales, del presente o del pasado, de la niñez de los actores o de los inicios del proceso de urbanización de la ciudad de Olavarría ${ }^{4}$.

\footnotetext{
${ }^{1}$ Universidad Nacional del Centro de la Provincia de Buenos Aires, Argentina.

${ }^{2}$ Esta investigación se inicia en el año 2010 y culmina en 2015 con la elaboración de la tesis de grado. Durante ese año se produce un cambio de gobierno con una impronta fuertemente neoliberal y conservadora, lo que cambia el contexto social y económico de forma drástica. En el campo de estudio actualmente y como efecto de éstas políticas, se observan dinámicas de cierre y apertura constantes y en breves lapsos de tiempo (meses) de pequeños comercios emplazados en garajes, en las viviendas particulares o en pequeños locales alquilados. Estas dinámicas remiten, en los imaginarios actuales, a "las épocas de crisis", particularmente en Argentina, a los años entre 1990 y 2001. Si bien no han sido integradas de forma específica al análisis del presente trabajo, se imponen como desafío para la continuidad de esta investigación.

${ }^{3}$ Esta práctica consiste en regalar al cliente algún bien de poco valor (como pueden ser los caramelos, chupetines, o verduras de hoja como cebolla de verdeo o perejil, una fruta, entre otros) Estos regalos se efectúan al momento del pago por parte del cliente y constituyen gestos de cortesía y estrategias para captar o mantener clientes.

${ }^{4}$ La ciudad de Olavarría se halla ubicada en el centro- sudoeste de la provincia de Buenos Aires de la República Argentina y constituye la ciudad cabecera del partido homónimo. Con una superficie de 7.715 $\mathrm{km} 2$, el partido cuenta con 111.708 habitantes, mientras que la ciudad concentra 89.721 habitantes (INDEC, 2010).
} 
Por otra parte en los últimos tiempos ${ }^{5}$, ha habido un surgimiento de un uso que podría denominar "vintage" o "retro"6 de la categoría "almacén" en tiendas comerciales de diversos bienes (cosmética, carnicerías, indumentaria, entre otros). En efecto, existen comercios que presentan en sus letreros nombres como "Almacén de aromas", "Almacén de carnes", "Almacén de lanas", incluso con una tipografía que recrea un formato "añejado".

Llamativamente, estas asociaciones nostálgicas con los almacenes dejan de ser enunciaciones de reivindicación en el contexto del "barrio periférico" de la ciudad, donde realicé el trabajo de campo "localizado" y referencié empíricamente el almacén de barrio. En estos contextos en los que "ir al almacén" constituye una práctica cotidiana, el almacén de barrio es "el almacén de la esquina", "el de la otra cuadra", el de "La Mary" o "lo del Alberto".

Este recorrido permite elucidar un entramado de prácticas y representaciones contradictorias: por un lado, un discurso "moderno", referenciado en los medios masivos de comunicación y en los eruditos (Gravano, 2005), en el que los almacenes de barrio y el fiado aparecen como reminiscencias del pasado en dos sentidos; o bien como prácticas comerciales que "se están perdiendo" o bien como un valor a recuperar del pasado, para resignificar y otorgar un "valor agregado" las formas de comercialización del presente. Por otro, la observación de "el almacén", como práctica vivida cotidianamente y como lógica de aprovisionamiento habitual, donde prácticas como el fiado, constituyen una necesidad estructural para la reproducción de las clases populares, y que son posibles en este contexto del "almacén de barrio".

La "desaparición” de lo que se significa como los típicos almacenes de barrio, se encuentra asociada a otros sentidos como "la pérdida de las relaciones de tipo familiar" (asociando lo familiar a lo informal) y “personales" en el ámbito comercial. El crédito bancario por ejemplo, constituiría la práctica "formalizada" e impersonal del fiado de la era moderna. Simultáneamente, la recuperación del almacén, en su uso vintage o retro, para denominar nuevos formatos comerciales "céntricos" con apariencia

\footnotetext{
${ }^{5}$ A partir de 2014 aproximadamente.

${ }^{6}$ El término vintage era habitualmente utilizado en las bodegas para referirse a los vinos producto de las mejores cosechas. Posteriormente su uso se amplió para hacer referencia a todo producto antiguo de buena calidad. No obstante, hoy se advierte un uso común para referirse a un estilo de producción actual que remite a una estética del pasado. Hay quienes distinguen este movimiento estético (de productos nuevos que evocan a antiguos) como retro, mientras que lo vintage sólo hace referencia a los objetos antiguos de calidad y con una estética específica. Concretamente ambos son una manifestación de la cultura posmoderna, en confrontación con la modernidad y el discurso progresista. Así, se recurre con nostalgia a elementos y estéticas del pasado.
} 
antigua, es recuperada por su atractivo semántico, condensando aquellos valores positivos de lo tradicional y lo moderno y suprimiendo al mismo tiempo las valoraciones negativas que ambos términos evocan.

Estos usos del almacén para referenciar tipos de comercios, ponen en evidencia dos cuestiones: por un lado, una limitación por parte de los marcos conceptuales economicistas para abordar el fenómeno, que desborda lo que se considera estrictamente como sistema de aprovisionamiento urbano. Por otro, que es necesaria la reconstrucción etnográfica de los sentidos y las prácticas que se naturalizan y condensan conflictivamente en la categoría nativa almacén.

A partir del trabajo etnográfico que pone en evidencia la existencia del fiado como práctica habitual, cotidiana e incluso necesaria para la reproducción de los que comúnmente se denominan, sectores populares, propongo la hipótesis de una necesidad estructural del fiado, que se encuentra vinculada a las prácticas de aprovisionamiento de los sectores populares, y que es posible en el ámbito de los almacenes de barrio. Recupero aquí la dimensión histórica del objeto y la producción de lo que denominé lo almacén (Del Águila, 2016) atendiendo a la comprensión de los almacenes como realidad material y simbólica.

Como segunda hipótesis sostengo que el proceso de reivindicación de los "almacenes de barrio" bajo el paradigma de la modernidad urbana, se manifiesta a partir de la reconversión de los formatos comerciales "tradicionales". Y es en este contexto que comprendo el proceso de esencialización y naturalización del almacén, en tanto sistema de aprovisionamiento, como también comprender los procesos de lucha por el acceso a los consumos colectivos en la ciudad capitalista (Gravano, 2015: 61-64).

Me pregunto finalmente por la especificidad de esta reivindicación de los almacenes de barrio en una ciudad media en relación con el imaginario metropolitano, en tanto modelo hegemónico respecto de "lo urbano" en las ciudades medias.

\section{El enfoque histórico-estructural}

Una de las problemáticas que pude rápidamente visualizar al comenzar con el trabajo de campo etnográfico, consistió en cómo abordar el almacén de barrio, sin reducirlo a su dimensión material o a su dimensión simbólica. En principio, porque el almacén de barrio no estaba allí, en ese barrio donde comencé a realizar las primeras 
entrevistas y observaciones, como una evidencia y manifiestamente como "el almacén de barrio". Ni el "típico", ni "el no tan típico". El almacén de barrio debía ser reconstruido etnográficamente, con sus múltiples manifestaciones empíricas y simbólicas, así como con sus dimensiones temporales y espaciales. El abordaje de estas observaciones requirió de una reflexión permanente en cuanto a la posibilidad de "cosificar" el objeto de estudio, mediante enfoques a-históricos o reduccionistas de los procesos socioculturales.

Me orienté así en la tarea de re-pensar la propia categoría nativa, "almacén de barrio", verificando luego que en la misma expresión, "de barrio", podría recuperar una línea de análisis para continuar el trabajo de investigación. Partiendo de concebir el barrio como algo más que una red de relaciones ampliadas en la cual se tejen los vínculos socio-económicos que acontecen cotidianamente en los almacenes; como algo más que un escenario en el cual los hechos transcurren, donde se inserta el almacén y sus prácticas.

Por otra parte, intentando dirimir el problema sobre las formas de análisis dicotómico-esencialistas, abordaré el análisis antropológico a partir de la visión dialéctica del proceso de construcción del objeto antropológico: "el almacén de barrio". Al tiempo que se pretende recuperar la idea de totalidad construida (histórica), el barrio como parte de un todo interrelacionado y no como como "comunidad cerrada", se plantea la necesidad de dar cuenta de los procesos concretos de la vida cotidiana, donde se tejen las significaciones. De esta manera se hacen partícipes y se les da voz a los mismos actores sociales, que son atravesados por las fuerzas históricas y estructurales.

El aporte de los enfoques marxistas a la comprensión de lo barrial, se desprende de su compresión de lo urbano y de la ciudad. A partir de Engels y su descripción dialéctica de la ciudad en su obra de 1845, "La situación de la clase obrera en Inglaterra", la problemática urbana es comprendida como producto de la desigualdad generada por el modo de producción capitalista. Las marcas de la pobreza son los barrios obreros y la comprensión dialéctica consiste en relacionar los barrios obreros con la posibilidad de existencia de barrios ricos. La existencia de barrios ricos se debe necesariamente a la existencia de barrios pobres. La ciudad industrial además, es comprendida como la "escena de la opresión" pero al mismo tiempo como el espacio social que posibilita la lucha por la liberación proletaria. En conclusión, "lo urbano", sostiene Gravano, 
... se constituye como problema a partir de la contradicción principal entre el desarrollo de las fuerzas productivas del capitalismo industrial -y su localización netamente urbana- y las necesidades de su propia reproducción como capital a través de la reproducción de la fuerza de trabajo en las cercanías de las locaciones, mediante el desarrollo de sistemas de infraestructura, consumos colectivos y servicios, esto es, el valor de uso de la ciudad misma (Gravano, 2013: 60).

Este enfoque, recupera la idea de totalidad, poniendo en relación dialéctica las separaciones de la visión dualista entre "tradicional-moderno", "desarrollosubdesarrollo", centro y periferia. El barrio, lejos de ser una realidad autocontenida, bajo este enfoque es comprendido como parte un todo interrelacionado. El barrio se constituye en indicador de la segregación urbana, producto de la apropiación desigual del excedente urbano (Gravano, 2015: 84).

Entonces el almacén de barrio, no es de barrio por el hecho de estar en el barrio, sino porque participa de alguna cualidad socialmente construida, que se naturaliza como "esencia", a partir del proceso ideológico de la des-historización de una "época base" que, según Gravano, es central para la categoría de lo barrial, como "producción ideológica".

El barrio "no constituye una comunidad o unidad espacial ecológica, natural ni exclusivamente física" (Gravano, 2003: 255), sino que "el barrio" es utilizado por los actores sociales para significar otras cosas, poniendo como ejemplo la expresión "muchacho de barrio". Esta noción, la del barrio como símbolo, como identidad y, fundamentalmente como producción ideológica, nos permite pensar en la existencia de un proceso de naturalización y esencialización de las relaciones sociales (por ejemplo, de la apropiación individual de los consumos colectivos, la desigualdad, la segregación, entre otros). Y así como el autor se pregunta, qué hay “detrás” de lo barrial como símbolo, retomo la misma pregunta en función de este trabajo: ¿qué quieren decir los actores cuando expresan que un almacén es "de barrio", "bien de barrio" y hasta “típicamente de barrio”?

El espacio urbano adquiere la forma de "barrios", debido a la segregación, lo que evidencia que el barrio constituya una referencia espacial de la lucha de clases. Autores marxistas como Castells (1974), Harvey (1977) y Singer (1981), hacen referencia a la naturalización de la segregación, como lógica del urbanismo en el capitalismo. Aparece así la idea del barrio en su función naturalizadora de los procesos de segregación social, pero también como producción histórica, al participar de la contradicción principal de la ciudad capitalista: en tanto su carácter necesariamente 
socializado de la existencia material (la ciudad como un recurso) y simbólica (la ciudad como un derecho) y la apropiación privada de su espacio (Gravano, 2003).

Esta perspectiva nos orienta en la línea de indagación de "lo barrial" del almacén como naturalización de un proceso social, y nos ofrece un indicio para la problematización del almacén en sí mismo. Partiendo de la observación etnográfica que interpela la comprensión de este fenómeno como un espacio físico de aprovisionamiento de mercancías por medio de intercambios económicos, problematizando al mismo tiempo lo económico en su sentido restringido "materialista", me vi en la necesidad de construir una categoría analítica que concuerde con este enfoque dialéctico. Introduje entonces la categoría de lo almacén, producida inductivamente a partir de ser etnográficamente informada, y adquiriendo al mismo tiempo capacidad explicativa del fenómeno, sin reducirlo a una de sus dimensiones.

\section{Los almacenes de barrio, sincronías y diacronías}

Situados en un tiempo y un espacio indefinidos, los almacenes transitan, en el universo de los imaginarios sociales, entre un pasado colectivo (en su identificación con los Almacenes de Ramos Generales o las Pulperías), un pasado personal (asimilados a los almacenes de la infancia) y un presente a veces algo difuso. Deambulan entre el espacio rural y el urbano, entre lo pueblerino y lo citadino, preferentemente en la periferia de las ciudades, los barrios populares y se reconoce en ellos relaciones más "personales" que "estrictamente económicas".

Para algunos sectores sociales $\mathrm{y}$, como veremos, para muchos teóricos, el formato comercial de almacén estaría desapareciendo paulatinamente, al ser suplantado por autoservicios, supermercados e hipermercados. Y con ello desaparecerían también aquellas lógicas informales y personales de comercio, como es el fiado. A partir de estos sentidos elaborados en los imaginarios sociales, tanto de sentido común, como en el erudito o en el massmediático, me pregunto acerca de la relación entre la estructuración social de una determinada modalidad de intercambio y de comercio, y las imágenes a ésta asociada.

El imaginario social es entendido aquí desde una concepción que intenta superar las dicotomías entre lo "real" e "imaginario". Por el contrario, los imaginarios sociales son comprendidos como producidos y reproducidos "dentro de relaciones contextuales 
e históricas, que son las que les asignan significados y sentidos a cada representación" (Gravano, 2005: 21). El espacio urbano y barrial sobre el cual son referenciadas las imágenes y representaciones, no son meros "entes fisicos", sino que consisten en espacios vividos por los actores. Los imaginarios constituirían mediaciones entre las determinaciones estructurales y los efectos de dichas determinaciones; en este sentido, Gravano sostiene que:

Las determinaciones estructurales no producen las exclusiones urbanas y el drama de la desocupación sino por mediaciones, como el imaginario, porque el concepto mismo de exclusión (lo mismo que el de marginación) constituye una representación, con un referente empírico-material concreto (Gravano, 2005: 21).

En tanto sistemas de representaciones histórica y culturalmente construidas, los imaginarios sociales se componen de diversas imágenes "que van dejando sus huellas, entre y a partir de las cuales se inscriben las <nuevas> en cada contexto histórico y social específico" (Silva y Boggi, 2015: 55). En diversas entrevistas y conversaciones espontáneas con actores sociales de sectores medios, los almacenes de barrio son inmediatamente vinculados y asociados a "los almacenes de ramos generales", a los primeros almacenes "de frontera con el indio" (asociados a los fortines) e incluso a las pulperías. A partir de estas recurrencias, me interesé en recuperar aquellos relatos históricos, académicos y no académicos, para poder reconstruir un marco interpretativo a fin de poder dar cuenta de cómo, en la conformación identitaria de los almacenes, se van superponiendo imágenes del proceso histórico vivido. Gravano utiliza la denominación de palimpsesto urbano (Gravano (comp), 2005; Gravano, 2015), para referirse a este escalonamiento o superposición de imágenes de la ciudad, que van dejando huellas en el devenir histórico y que se manifiestan (conflictivamente) en la construcción de identidades del presente.

Sobre los desarrollos teóricos (Gravano, Silva y Boggi, 2016; Gravano, 2005) en torno a las imágenes vigorosas (Lynch, 1966) de la ciudad de Olavarría ${ }^{7}$ que, a partir de su proyección histórica se han ido superponiendo como secuencias de imágenes, existen dos en particular que se vinculan estrechamente con imágenes sobre los almacenes de barrio. Me refiero a la ciudad de frontera y a la ciudad de los tribalismos blancos. Estas imágenes, que se irían sedimentando una tras otra, como "huellas", poseerían

\footnotetext{
${ }^{7}$ Se hace referencia a Olavarría en particular, pero se comparten con otros centros urbanos de la región pampeana.
} 
alternativamente suelo fértil para su expresión ulterior, conviviendo con otras, fusionándose u oponiéndose.

La ciudad frontera hace referencia a imágenes vigorosas en torno a la defensa de la frontera contra el indio,

... que conformará una de las imágenes más vigorosas mediante la que se constituye la identidad de la ciudad posterior y que se refleja en el imaginario erudito local cuanto oficial: su carácter épico-fronterizo, de los blancos contra los indios (Gravano, 2005: 37).

A esta imagen se superpone otra, la de los tribalismos blancos, que remite a la representación de "que la ciudad de Olavarría está signada por su carácter étnicamente blanco... una imagen de ciudad europea y caucasoide" (ídem: 40). Esta misma idea de tribalismos blancos se asocia a "la representación de un crisol de razas, traducido luego a la imagen de crisol social" (ídem: 40, el destacado es del autor).

La recuperación de estos desarrollos se vincula con aquellas imágenes con las que pude reconstruir etnográficamente el sentido de lo almacén. Si bien no he podido realizar un análisis en profundidad de los mismos, es importante al menos mencionar estas asociaciones, que serán ampliadas en trabajos ulteriores. Me refiero a la noción que relaciona los almacenes de barrio con los primeros almacenes de fortines: "allí donde hubo un fortín, existió un almacén. Somos parte de la historia" expresaría un almacenero local de unos setenta años. Por otra parte, esta imagen se superpone a la idea del comerciante-almacenero - blanco y europeo, y la "introducción" de las relaciones "civilizadas" al campo.

Una de las asociaciones más recurrentes que se han explicitado durante el transcurso de esta investigación, es la del almacén de barrio con los "almacenes de ramos generales". Estos tipos de comercios, escasos pero aún vigentes en algunos medios rurales del presente, eran los únicos centros de aprovisionamiento de las primeras poblaciones de la región pampeana ${ }^{8}$ entre mediado y fines del siglo XIX. Por qué se presenta esta analogía al interrogar por las imágenes, recuerdos y sensaciones que ésta palabra produce, es uno de los interrogantes que guían la indagación hacia las fuentes desde donde se proyectan estas imágenes.

\footnotetext{
${ }^{8}$ Región geográfica que, en Argentina, abarca las provincias de Buenos Aires, Entre Ríos, Santa Fe, sur de Córdoba, La Pampa y Sur de San Luis. Se caracteriza principalmente por su extensa llanura (estepa), clima templado y la alta fertilidad de sus tierras.
} 


\section{De la Pulpería a los Almacenes de Ramos Generales}

En el periodo 1875-1914, a nivel del capitalismo industrial mundial, se observa una transformación en las actividades distributivas y surgen novedosas técnicas de venta, nuevas formas de organizarlas (como la división entre "al por menor" y "al por mayor”), complejizándose las cadenas de distribución de bienes; surgen asimismo nuevas modalidades de presentación de los bienes en unidades minoristas, se conforman las marcas, aparecen las publicidades como técnicas de venta, diseño de envases, entre otros múltiples factores. No obstante, para la Argentina, este proceso tuvo diferencias temporales y espaciales, teniendo en cuenta las particularidades de cada una de las regiones (Lluch, 2002-2003; Di Nucci y Lan, 2008; Ablin, 2012). Fue en la región pampeana que el mercado experimentó profundos cambios tanto cualitativos como cuantitativos, particularmente a fines del siglo XIX, cuando a partir del boom exportador, se produjo la transición gradual de las Pulperías a los Almacenes de Ramos Generales. Es en este período que se consolidan los almacenes como las unidades típicas de venta minorista, siendo los principales factores que contribuyen a este proceso, "la expansión agraria, el incremento poblacional, el desarrollo tecnológico de la mano del ferrocarril y el telégrafo, la producción en masa de alimentos, [y] los cambios en el consumo" (Lluch, 2002-2003: 139).

\section{Los Almacenes de Ramos Generales en el capitalismo del agro argentino}

Los estudios históricos que toman como objeto de estudio a los comercios rurales son escasos. Sólo en los últimos diez años, se ha fijado el interés en el rol de este tipo de $\operatorname{comercios}^{9}$, en diversos contextos sociopolíticos de la historia argentina. En el marco de estos estudios de enfoque regional y micro-analíticos (estudios de caso), es

\footnotetext{
${ }^{9}$ Para mencionar los más relevantes, citamos el trabajo de Andrea Lluch, "Comercio y crédito agrario. Un estudio de caso sobre las prácticas y lógicas crediticias de comerciantes de campaña a comienzos del siglo XX en La Pampa", Boletín del Instituto de Historia Argentina y Americana Dr. Emilio Ravignani versión On-line ISSN 1850-2563, 2006; Susana Bandieri, "Bandoleros, almaceneros y acopiadores. Familias comercio y poder en el Territorio Nacional del Neuquén", en XVII Jornadas de Historia Económica, Tucumán, 2000; Julio Djenderedjian, "Sangre y nervio de la monarquía. Mercados locales y comercio interior en el sur del litoral en las postrimerías de la colonia", XVIII Jornadas de Historia Económica, Mendoza, 2002; Diana Duart, "El crédito como relación social: algunas consideraciones sobre los vínculos comerciales en el área de la frontera bonaerense siglo XIX", Jornadas "Problemas y debates del temprano siglo XIX", Universidad Nacional de Mar del Plata, 2005; y Roberto Schmit, "Intercambios mercantiles y medios de pagos", ponencia presentada en Seminario la historia económica hoy: balances y perspectivas, AAHE, Asociación Argentina de Historia Económica, Buenos Aires, 2005.
} 
abordado el sistema de crédito en relación al desarrollo del capitalismo agrario, sin perder de vista las relaciones sociales cotidianas que van construyendo dichos vínculos.

Según Lluch durante la expansión agraria de la segunda mitad del siglo XIX y primer tercio del XX y la conformación del capitalismo en argentina, los comercios rurales denominados "Almacenes de Ramos Generales", tuvieron un importante rol como intermediarios comerciales y financieros:

Articulando este proceso [la expansión agraria y el desarrollo del capitalismo en argentina] se desarrollaron una serie de mecanismos de intermediación, encargados de canalizar la producción de la campaña hacia los puertos, además de proveer una serie de insumos, maquinarias, alimentos y financiación a los productores. Los almacenes de ramos generales -surgidos de la adaptación que implicó la reconversión de los anteriores comercios o pulperías- fueron unos de los más significativos intermediarios comerciales y desempeñaron múltiples funciones en el proceso de incorporación de las economías locales al mercado internacional (Llunch, 2006: 2).

Este análisis da cuenta de una relación funcional de estos comercios en tanto oficiaban de nexos entre las casas cerealeras y los bancos, constituyéndose en agentes financieros del ciclo agrícola. Dicha acción mediadora consistió en el otorgamiento de créditos ${ }^{10}$ a chacareros, tanto para la compra de bienes, de servicios o de dinero. Los chacareros (grandes, pequeños y medianos) podían de esta manera acceder a la compra de herramientas, de alimentos, o bien de préstamos en dinero, con la obligación de pagar al comerciante (siempre con una tasa de interés) al final de las cosechas. En sí consistió en un sistema comercial en principio adaptado a los ciclos económicos del agro. Las características peculiares de este sistema derivan de aquellos mecanismos informales sobre los cuales se garantiza el funcionamiento del mismo, como el uso de la libreta como "materialización del vínculo entre almacenero y cliente" (Lluch, 2006: 6) y la confianza personal como garantía de pago. La trascendencia de las relaciones personales en este tipo de comercios es remarcada en los diversos análisis, así como el carácter de institución multifuncional.

Los “Almacenes de Ramos Generales", como así se denominaron en este período a los comercios rurales en Argentina, se caracterizaban por la gran variedad de rubros comerciales que abarcaban, entre ellos venta de alimentos, herramientas, carruajes, materiales para el campo y la construcción, vestimenta, talabartería, librería, préstamos personales en dinero (con interés) entre muchos otros, intentando abastecer

\footnotetext{
${ }^{10}$ Término que describe la acción de vender en el presente bienes, dinero o servicios, con la promesa de pago en el futuro.
} 
todas las necesidades de los pequeños poblados y chacareros en un solo lugar. Incluso en las mismas instalaciones funcionaba una cantina, configurando un punto de reunión de los hombres del poblado y los campos vecinos. Y hago énfasis en "hombres" ya que, tal lo evidencian las diversas fuentes consultadas, para este período y en la región que nos ocupa, quienes estaban al frente de los almacenes eran hombres, inmigrantes y españoles principalmente.

Existieron características comunes en los edificios de los almacenes de principios del siglo $\mathrm{XX}$, edificios que hasta hoy día pueden observarse en pueblos y ciudades (Ver: Imágenes 1 y 2).

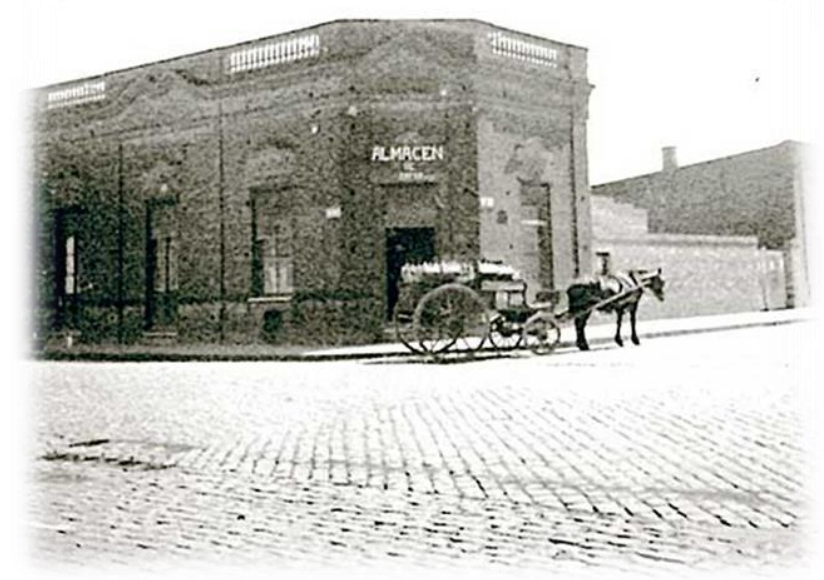

Imagen 1 - Almacén "El Combate” de Nicolás Flechoso, principios del siglo XX. Ciudad de Olavarría. Fuente: El Popular Medios.

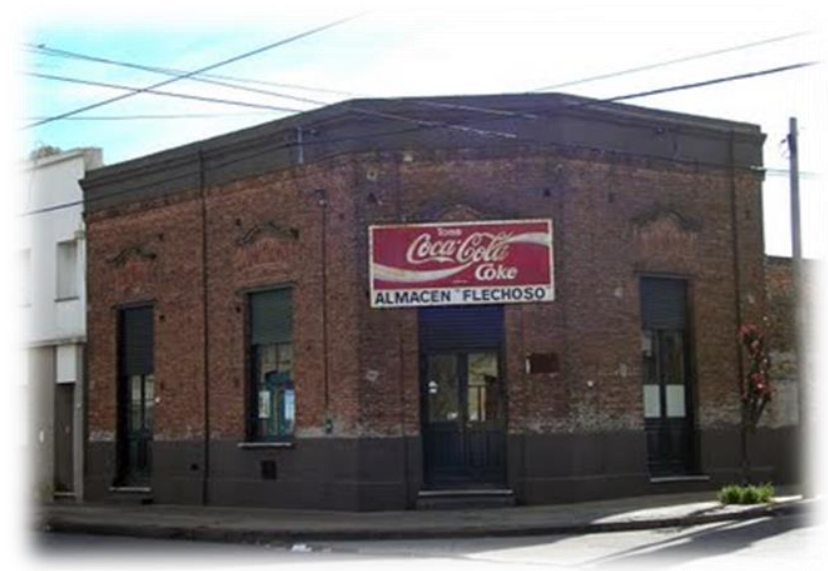

Imagen 2 - Almacén "Flechoso" en 2011. 
Las imágenes 1 y 2 corresponden a un mismo almacén, legendario de la ciudad de Olavarría perteneciente, a partir de 1937 y hasta 2011, a la familia de apellido Flechoso. Este tipo de construcciones (edificados la mayoría- entre 1900 y 1920) fue característico de los Almacenes de Ramos Generales, con sus frentes imponentes, construidos casi siempre en las esquinas en ochava. Al interior podía apreciarse un amplio y largo mostrador que separaba al almacenero de sus clientes.

Diversos análisis históricos ponen de relieve la importancia de la multifuncionalidad de este tipo de comercios hacia fines del siglo XIX y principios del siglo XX, es decir, de aquellas funciones que exceden las netamente económicas y que de alguna manera colaboran para cubrir las necesidades de sociabilidad de una comunidad. James Scobie por ejemplo, imaginando, para las primeras décadas del siglo $\mathrm{XX}$, un escenario rural argentino marcado por el aislamiento social, le otorga al almacén de ramos generales la importancia de satisfacer diversas necesidades sociales además de constituir la institución social que contrarresta la fuerza centrífuga de la vida cotidiana de las sociedades principalmente ganaderas de dicho período.

El almacén general fue la única institución social en la Argentina rural... En muchos sentidos ocupó el lugar de la iglesia, la escuela, el club y la plaza, todo lo cual brillaba por su ausencia en las pampas (Scobie, 1968: 62).

Para la región pampeana, Lluch vincula la multifuncionalidad del almacén al desarrollo local de los pueblos y a la capacidad de inserción de estas economías locales en el mercado internacional. "Tengo que hacer las veces de médico, comisario, comerciante, defensor de oficio", de esta manera titula la autora uno de sus trabajos, tomando dicha expresión de una carta escrita por un almacenero de La Pampa (Argentina) de principios del siglo XX, Don Severino Fernández. Sostiene que los almacenes actuaron como "agentes articuladores del espacio” (Lluch, 2002-2003: 158), como un nexo tanto económico como social entre los incipientes poblados y los principales centros urbanos de la época, y fundamentalmente como agentes de gestión social dentro de las mismas comunidades. En este sentido la autora expresa:

El oficio de comerciante requería [...] tener presente que: <un hombre que no se hace de amigos, no se hará de clientes jamás>.

Reglas del quehacer mercantil se vinculaban además, con ser lugar de encuentro, referencia y acceso a servicios por estar en cruces de caminos y sin estar inmediatamente ligados al ferrocarril [...] Cada año se reunían los pobladores para celebrar bautismos y bodas. Hasta allí llegaban los pedidos para buscar medicinas y atención médica [...]. Asimismo, la información que cumple un papel central, era 
otro de los servicios ofrecidos [...] en su rol de comerciante se mantenía actualizado por los medios nacionales (era suscriptor de diarios como La Prensa, Caras y Caretas y La Nación) y por las noticias recibidas en las cartas de sus proveedores y amigos de Buenos Aires. Sus conocimientos de cuestiones legales, lo hacían también ser consultado por los productores de la zona y por sus cartas los encontramos interviniendo en testamentarias de gente que lo nombra responsable o albacea (Lluch, 2002-2003: 150).

La acción de los almaceneros en esta época es pensada como un motor del desarrollo económico y social, del crecimiento poblacional y de la urbanización, a partir no solamente de la facilitación de créditos para el consumo y la inversión, sino de otras múltiples actividades ya mencionadas anteriormente.

En el conjunto de las descripciones de historiadores en relación a los comercios de ramos generales, se destaca otra peculiaridad que se enfrenta y contrapone a la imagen de comerciantes-filántropos (que seguirían la máxima: fiar sin mirar a quien), que podría en un primer momento concluirse de las descripciones anteriores. Esta particularidad tiene que ver con la imagen de comerciante usurero. Lo paradójico del hecho se presenta en los mismos registros históricos y análisis de historiadores: la contradicción entre una institución que promueve y desarrolla los lazos sociales de una localidad, además del desarrollo económico, y un comercio/comerciante (versus institución) que actúa de modo interesado e individual, en función de sus propios intereses, sin medir las consecuencias sociales de su accionar.

Hallamos de esta manera descripciones referidas a jerarquizaciones de clientes según su reputación y solvencia, como factor crucial a la hora de otorgar créditos, más que nada en aquellos casos de comerciantes que no llegaron a la quiebra económica por dar crédito a todo el poblado. Y paralelamente, el empleo de la extorsión y la coerción a partir de la utilización del interés en las cuentas retrasadas, hecho que podía culminar en la expropiación de tierras de los chacareros:

[...] el interés funcionaría a modo de "penalización" de las deudas en cuentas corrientes impagas. El interés se cobraba sobre los saldos pendientes de pago al momento del vencimiento pero calculados sobre la fecha de origen del crédito (inicio de operaciones), aplicándose una tasa por todo el período que funcionaría entonces a modo de multa o de astreintes.

Este tipo de práctica estaría orientada a sortear la dificultad para manejar un crédito intratemporal y buscaría, a modo de hipótesis, mejorar la previsibilidad y actuar como elemento de presión: "El Sr. José Jaca hasta la fecha no hizo entrega de nada, hace unos días estuvo en el pueblo y no se presentó en casa. Ya vendrá para los dos meses que promete si les parece haremos cuenta con intereses haber [sic] si se apura más y dará entrega (Lluch, 2006: 17). 
Uno de los registros más contundentes en torno a este aspecto usurero "negativo" de algunos comerciantes en el país, es el de Juan Bialet Massé (1846-1907), un médico y abogado catalán, residente en Argentina desde 1873, quien en 1904 elaboró un informe sobre la situación de las clases obreras argentinas, a pedido del entonces Ministro del Interior Joaquín V. González, durante la presidencia de Julio A. Roca. Vale la pena citar un relato que este autor realiza luego de uno de sus viajes por el Chaco, donde se interioriza en las relaciones entre pueblos nativos, mocovíes y tobas (Q'om), colonos y criollos, opinando lo siguiente:

\begin{abstract}
Allí supe que la Colonia Obligado se había formado con 2000 indios de su raza; pero supe también que son excelentes labradores y cosecheros de maní; supe que se les pagaba con el vale de proveeduría, y que sólo a los colonos italianos les pagaban en dinero, y que colonos e indios eran explotados por los almaceneros; supe más, lo oí: allí, en aquella región, no hay mendigos; una turca forastera se acerca a un almacén, pide una limosna; jamás vi cara más cruda para echar a un pobre [...]

Es ahí donde el indio aprende lo que es el catálogo de venenos alcohólicos, única cosa que se les enseña; es ahí donde los explotan sin medida [...]

Se dirá, ¿cómo es posible que a gente tan buena se le atribuyan tan malas pasiones y se la pinte con tan negros colores? ¿Qué hay en perjudicarlas?

Debe decirse de una vez y francamente: los terrenos que poseen los indios son excelentes (Bialet Massé, [1904] 2010: 57).
\end{abstract}

La variedad de relaciones que se establecieron en este periodo en el territorio argentino entre comerciantes almaceneros y sus clientes es inabarcable. Cada historia presentará particularidades infinitas. Existieron casos de almaceneros que se han quebrado económicamente por el otorgamiento indiscriminado de crédito. Pero también existieron quienes se volvieron grandes empresarios prestamistas, con gran cantidad de propiedades, como campos e inclusive inmuebles en los principales centros urbanos.

\title{
Del almacén al supermercado
}

En Argentina, el fenómeno del supermercadismo, al igual que el desarrollo de almacenes de ramos generales, no constituyó un proceso evolutivo secuencial y homogéneo en toda la región. En línea con exposiciones anteriores, existen desarrollos regionales específicos, con características particulares que no pueden ser generalizados. Sólo de modo general puede decirse que es a partir de la década de 1950 que el comercio minorista de productos alimenticios comienza a presentar cambios profundos a nivel mundial. Los principales rasgos de los comercios previos a 1950 eran la alta especialización por grupos de alimentos, la atomización o pequeña escala de los 
negocios (Ablin, 2012; Federación Argentina de Empleados de Comercio y Servicios, FAECyS, - Junio, 2011). Sólo existían grandes establecimientos como los Almacenes de Ramos Generales que, aunque no consistieran en mega superficies, abarcaban múltiples rubros y funciones en los espacios suburbanos y rurales.

Es a partir de la segunda mitad del siglo XX que la comercialización adquiere nuevas técnicas, respondiendo de alguna manera a la progresiva concentración de capitales y modificaciones en el tejido empresarial a nivel mundial. En cuanto a las nuevas técnicas, se experimenta el surgimiento del autoservicio, la góndola y la caja cobradora aislada frente a las puertas de salida, que muchos comerciantes reemplazarán, a veces de modo total, a veces de modo parcial, en sus locales (Di Nucci y Lan, 2008).

En la década de 1960, este proceso va a acentuarse. La modalidad de venta “auto-servicio", será implementada por supermercados y luego hipermercados ${ }^{11}$, existiendo una tendencia al crecimiento de las dimensiones (en superficie cubierta) de los establecimientos. Esta acumulación y concentración de capital estará vinculada a las nuevas configuraciones espaciales urbanas y hábitos de consumo. Los súper e hipermercados serán definidos como grandes cadenas comerciales, caracterizadas por la concentración de capital, las grandes superficies, la venta de variedad mayor de productos en relación al comercio tradicional y presentan la capacidad de exigir condiciones de calidad y precios al sector productivo.

Es en la década de 1980 que, luego de una crisis inflacionaria de la década anterior, se abre la inversión extranjera lo cual impulsó el arribo de grandes cadenas internacionales como Carrefour (de Francia) en 1982, Makro (de Holanda) y Jumbo (de Chile) en 1988. La doctrina neoliberal y la democracia de mercado del período 19902001, aceleran este proceso. Se abren en la Argentina mayor cantidad de firmas internacionales (Wal-Mart, en 1995), y asimismo se crean grupos nacionales como Coto y La Anónima. (FAECyS, 2001).

Las mayores transformaciones en el sistema minorista de la alimentación sin embargo, se manifestarán en la década de 1990, generados mayormente por los cambios macroeconómicos a nivel país, debido a la apertura comercial, la convertibilidad, la falta de regulación por parte del Estado en general, como el mantenimiento de la estabilidad de precios y las reglas comerciales. Es en este período que se experimenta la

\footnotetext{
${ }^{11}$ Los primeros supermercados con autoservicio surgen en las principales ciudades de Estados Unidos. Inicialmente ligados al comercio de mercaderías, posteriormente se implementarán en otros ramos como la venta de discos, perfumería, ropa, entre otros. Pero es en Francia, en 1963 que se inaugura el primer hipermercado, Carrefour, instalado en la periferia de París. (Di Nucci y Lan, 2008).
} 
apertura de los famosos supermercados chinos a partir de la inmigración de familias provenientes en su mayoría de China y Taiwán.

La imagen en general de esta época era la de grandes empresas que comenzaban a monopolizar el mercado. Principalmente a partir del cierre de los pequeños y medianos comercios y por la absorción de las medianas cadenas por parte de los grandes grupos. Pero además, por la aparente menor cantidad de pequeños comercios minoristas tradicionales y fundamentalmente por la gran adaptación de estas empresas a captar consumidores de todos los niveles socio-económicos. Las grandes superficies fijaron una nueva organización del espacio y nuevos modos de vivirlo.

\section{El comercio a partir del neoliberalismo en Olavarría: del super a la vuelta al barrio}

Para el caso de Olavarría, en 1995 se abre el primer supermercado denominado Casa Tía, comercio que se instalaría, tras un arduo debate público en torno al "lugar", en el centro de la ciudad, luego de la adquisición de un terreno municipal. Ese terreno poseía un edificio construido en 1930 para la Escuela Normal (que databa de 1910) y que contaba con una larga historia de instituciones públicas que lo habían utilizado posteriormente $^{12}$. El edificio histórico debía ser demolido y Los Talleres Municipales que funcionaban en ese momento, debían ser re-localizados.

Los grandes supermercados llegaban a ciudades como Olavarría en el marco de una crisis que se iba profundizando, garantizando puesto de trabajo e inversión local. No obstante, la política económica de trasfondo (el neoliberalismo y la democracia de mercado, sostenidos por el régimen de convertibilidad) más que paralizar la crisis, ahondaron la desigualdad. La pérdida de puestos de trabajo, el cierre de empresas y fábricas, comenzó a marcar el panorama que desembocaría en la crisis que inauguró el segundo milenio en nuestro país. Como señalan Josefina Di Nucci y Diana Lan:

\footnotetext{
${ }^{12}$ Casino de Oficiales de Ejército, como Escuela Municipal de Música y donde funcionarían finalmente los Talleres Protegidos.
} 
El año 2002 fue un año fuertemente recesivo que comenzó con la devaluación del peso y las restricciones financieras agudizadas respecto al año anterior; como consecuencia, falta de liquidez producto del <corralito>, inexistencia de líneas de financiamiento, incertidumbre en materia de precios, presencia de cuasi-monedas, entre otras cuestiones, provocaron una caída en las ventas de los supermercados que no había tenido precedentes, ni siquiera en el año anterior. (Di Nucci y Lan, 2007: $3)$.

Es a partir de 2000 que se genera un estancamiento relativo del formato supermercado-hipermercado, re-estableciéndose el autoservicio y los comercios tradicionales (con el todo suelto) como principales puntos de consumo. Junto a este proceso de readaptación de los consumidores a nuevas modalidades de aprovisionamiento, surgen estrategias comerciales acordes a esta situación. Entre ellas, el empaque más pequeño, las segundas y terceras marcas, las marcas de las propias cadenas de distribución, mayor frecuencia en la realización de compras y de menores cantidades y, lo que nos interesa en especial, la búsqueda de nuevos canales de distribución con la vuelta al barrio y la compra de productos sueltos.

Entre la última década de 1990 y la primera década de 2000 se abren en Olavarría pequeños comercios de venta de productos alimenticios con algunas particularidades. Estos son instalados en uno de los sectores de las casas particulares, a partir de la adaptación del ámbito privado al ámbito público comercial, particularmente en zonas de barrios periféricos, a escasas distancias entre sí y siendo característica la venta de productos a granel, más conocidos como los "todo suelto"13.

Las políticas económicas implementadas en el país a partir del año 2003, aunque continuando dentro del paradigma de acumulación de capital, permitieron que diversos sectores productivos vinculados a la industria, aumentaran la generación de valor, la creación de puestos de trabajo y el consumo. Dichas políticas, de modo general, se vinculan a la sustitución de importaciones, al rechazo a los tratados de libre comercio, a la estatización de empresas como YPF y al anti-neoliberalismo. Asimismo las políticas sociales, como la Asignación Universal por $\mathrm{Hijo}^{14}$ (AUH) y los planes de construcción

\footnotetext{
${ }^{13}$ Estos comercios, aún existentes en menor medida, presentaban carteles con leyendas como "todo suelto", especificando luego el rubro: artículos de limpieza, alimentos, etc. Dicha denominación se debe a que este tipo de bienes son comercializados sin que sean empaquetados previamente por unidad o por peso. Actualmente es habitual la venta de productos de limpieza bajo esta modalidad, re-utilizando envases de bebidas para verter por ejemplo productos líquidos los que muchas veces son aportados por los propios comerciantes o bien son los mismos clientes quienes los llevan.

${ }^{14}$ La Asignación Universal por Hijo es un beneficio que otorga el Estado a los/las hijos/as de personas desocupadas, que trabajan en el mercado informal o que ganan menos del salario mínimo, vital y móvil. Consiste en el pago mensual de una suma de dinero por cada hijo, existiendo un plus para aquellos hijos con capacidades diferentes.
} 
de viviendas, han representado una mejora en las condiciones socioeconómicas de los sectores populares.

En cuanto al sector socioeconómico analizado, son las cadenas de supermercados orientales que comienzan a competir fuertemente con los almacenes y no las grandes superficies como Carrefour y Wal-Mart, que apuntan a un mercado con mayor poder adquisitivo, además de ser reguladas en la Provincia de Buenos Aires, por la Ley de Grandes Superficies 12.573, sancionada en 2001 y con plena vigencia desde 2002. Este proceso de apertura de supermercados orientales, fue incrementándose en la región y cobrando importancia y peso, principalmente para el sector de mini mercados y almacenes.

Según la perspectiva de la propia Federación de Autoservicistas, Almaceneros, Alimentarios y Afines de la Provincia de Buenos Aires (FABA):

\begin{abstract}
Desde la sanción de la Ley 12.573, producida en diciembre del año 2000, derogando la anterior Ley 12.088, y su plena vigencia desde el año 2002, solo se han otorgado aproximadamente 210 factibilidades provinciales, siendo mayor el porcentaje a establecimientos supermercadistas, siguiéndole casas de electrodomésticos y por último los formatos homecenter y tiendas por departamento, por lo que se puede decir que la Ley cumplió con los objetivos buscados por las entidades gremiales empresarias comerciales, como FABA[...] (Análisis de la implementación de la Ley Provincial 12.573, reunión del 20 de Agosto de 2014. Presidente Gustavo Fuertes)15.
\end{abstract}

En el diario "El Popular" de Olavarría, en su edición digital del día 22/11/2011 entrevista a un referente local de la Confederación Nacional de Almaceneros:

Minoristas promueven la regulación de la actividad en los hipermercados

$\ldots<$ esta legislación significaría defender al comercio minorista en general, las economías regionales e incluso la defensa de los hogares. En nuestro caso, los monotributistas son pymes familiares que pretenden mejorar su calidad de vida: queremos ingresar en el crecimiento que se desarrolla en el país; todo el mundo quiere progresar>, sintetizó Bianchi. <Nuestra actividad nació con el país y los comerciantes minoristas siempre participamos de actividades sociales, como sociedades de fomento, cooperadoras. Siempre estuvo vinculado el almacenero de barrio a esa actividad sin fines de lucro>, recordó (Diario El Popular, 22/11/2011).

${ }^{15}$ http://www.faba-minoristas.org.ar/faba_ley_12573.html 
Pero más allá de la efectiva implementación de las diferentes estrategias político-económicas con vistas a proteger los pequeños y medianos comercios locales, la imagen de la pérdida o desaparición de los "típicos almacenes de barrio" se ha consolidado paradójica y contradictoriamente, en los discursos del sentido común y mas mediático.

\section{De qué tiempo es este almacén}

Parafraseando a Kevin Lynch, atendiendo a su obra ¿De qué tiempo es este lugar? (Lynch, 1972), podemos preguntarnos por la dimensión temporal y espacial en que los actores sociales ubican imaginariamente los almacenes de barrio.

\footnotetext{
Para mí... El almacén de barrio me recuerda al almacén de mi barrio... yo vivía en el Barrio "El Brillante" y allá íbamos a Lo de Pepe. Me acuerdo clarito, pero clarito el olor de ahí, ¡Tenía una mugre! Y creo que sigue estando el pobre, está viejo...

Pero te decía, el Pepe era un típico almacenero: gruñón, charlatán, te pasabas horas y horas ahí hasta que terminaba de hablar y te atendía. Sucio, decían que usaba las pilas que luego te vendía (Silvana, empleada estatal, 51 años).

Vos me decís almacén de barrio y yo me acuerdo del almacén de cuando era chico, a La Mary [...] (Hombre, docente, 32 años).

[...] fijate lo que me vengo a acordar. Cuando yo era chica, yo vivía en [...], un pueblo de la zona de Pringles. Y estee... y había un almacén, el de Varela. Vendía de todo el viejo, podías ir a comprar desde lana para tejer, hasta botas, pala ancha... El Viejo le daba fiado a casi todo el mundo y anotaba en lo que se llamaba, no sé si ahora es igual, la libreta (Mujer, dueña de empresa de servicios, 50 años).
}

En las redes sociales (Facebook), existen memorias de almacenes de barrio escritas en comentarios a una publicación realizada en un grupo de la misma red, llamado "Los fabulosos setenta" (Ver imagen 3). Lo interesante de este hallazgo, consiste en poder registrar experiencias similares vividas en diversos lugares de Argentina. Esta publicación alcanzó 3487 "me gusta", 998 comentarios y fue 6500 veces compartido por otros usuarios de la red, dándonos la pauta de ser una temática que despierta interés y es motivo de intercambio. 


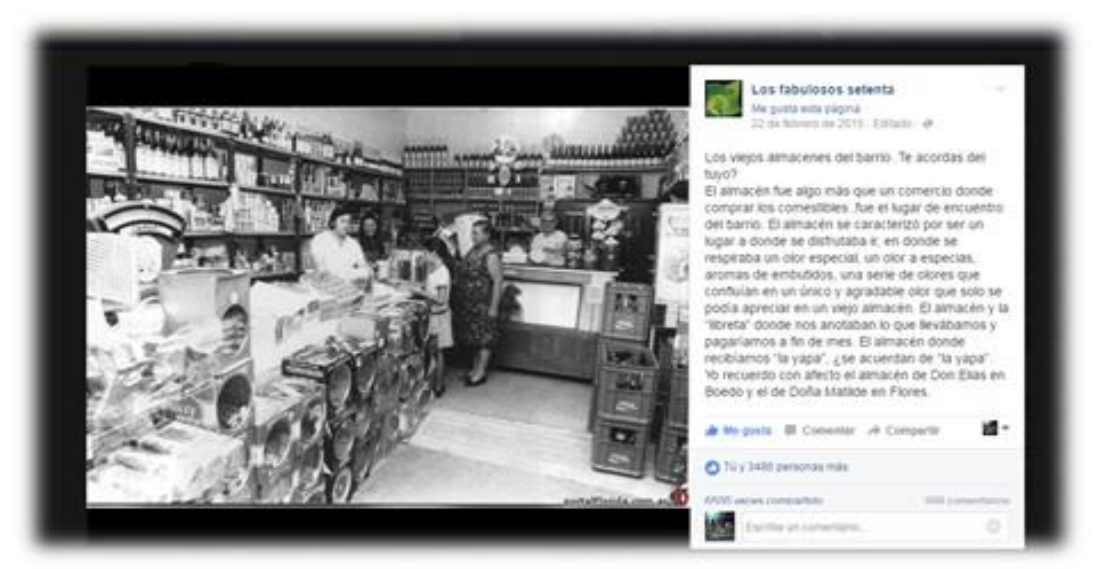

Imagen 3 - Grupo de la red social Facebook "Los fabulosos setenta" 6/5/2016. 11:30hs.

Los viejos almacenes del barrio. ¿Te acordás del tuyo? El almacén fue algo más que un comercio donde comprar los comestibles, fue el lugar de encuentro del barrio. El almacén se caracterizó por ser un lugar a donde se disfrutaba ir, en donde se respiraba un olor especial, un olor a especias, aromas de embutidos, una serie de olores que confluían en un único y agradable olor que solo se podía apreciar en un viejo almacén. El almacén y la "libreta" donde nos anotaban lo que llevábamos y pagaríamos a fin de mes. El almacén donde recibíamos "la yapa", ¿se acuerdan de "la yapa". Yo recuerdo con afecto el almacén de Don Elias en Boedo y el de Doña Matilde en Flores.

Comentarios (4 de 996)

Silvana Fernandez 16 Yo recuerdo el almacen17 de Don MIGUEL en bahia blanca y miranda !!!!!! Pero hoy tengo el de Leonardo Lombardo en chivilcoy y tres arroyos un grosso !!! Los dos de FLORESTA !!!!

Lidia Noga Siiiii.,la almacen de la corchito le decian.......el mejor queso vendia y antes te daban a probar y la yapa....en rosario ,saladillo barrio magnano....

Miriam Magiarobe Si esos momentos para mi que naci en una almacen mi mama era la dueña y mi hermana y yo atendiamos siempre con una sonurisa hasta hora en cuentro clientes que me dice me acuerdo dr vos cuando atenfia almacen y soderia graciad por el recuerdo.

Sonia Sillivani Época del azúcar refinada o a terrones, según el precio. Todo se vendía suelto, te lo envolvían en papel que le hacían un repulgue con orejitas. Del champoo en sachet individual marca Nirvana, Época de la yapa, el almacenero nos decía, si se pasaba del...

El almacén es representado en el imaginario hegemónico en la actualidad como una reminiscencia de una tradición de pueblo y del pasado. Tradición que aún "perdura" en algunos barrios periféricos. "Al principio se trabajaba como almacén de barrio [...] E inclusive en algunos almacenes de la periferia siguen haciéndolo", opinaba Julio de Felice en la nota periodística titulada "Con la esencia de almacén de barrio". Y no solamente el tipo de comercialización se valora como lo tradicional, lo de un principio

\footnotetext{
${ }^{16}$ Todos los nombres han sido modificados.

${ }^{17}$ Para mantener la originalidad de las expresiones en esta red social, no han sido modificados los errores de escritura.
} 
y lo original, como son la atención del almacenero o almacenera detrás del mostrador, el fiado-cuenta corriente o libreta frente al auto-servicio, las góndolas y la tarjeta de crédito, sino que además "algo de aquella costumbre", que "se está perdiendo". Existe algo de la "costumbre actual", que es distinta a "la de antes". Pero que si bien se ha perdido, también se oye decir que "algo queda", con "los viejos clientes", con los clientes "de toda la vida".

Al interrogar a diversos actores sobre las experiencias en los almacenes de barrio, en general se registra una invocación a "sus almacenes". "¿Te acordás del tuyo?", dice a modo de propuesta la cita de Facebook. Esta apropiación del almacén, se concreta en muchos casos a partir de un referente que está en el pasado, como se observa en las citas, aunque el almacén pueda seguir existiendo en el presente etnográfico: “yo me acuerdo del almacén de cuando era chico, La Mary”, recordaba un docente al cual entrevisté, quien luego me diría que el almacén aún existe, y su dueña, La Mary, sigue atendiéndolo "detrás del mostrador".

Existe una conflictividad de los almacenes que se manifiesta como "lugar común" en las distintas experiencias narradas, y que surgen de la tensión entre la confianza/desconfianza producto del conocimiento mutuo entre comerciante y almacenero/a. Silvana contaba sobre "su almacenero" quien usaba las pilas que luego vendía, o modificaba la balanza para sacar algún tipo de ventaja económica mediante el engaño. Este tipo de situaciones constituyen conflictividades comunes en los imaginarios en torno a los almacenes, pero que se manifiestan con una tonalidad nostálgica o como "cosa del pasado". Al indagar en cuál sería la imagen que opera como lo opuesto a este lugar común, el súper se constituye en aquella imagen contrapuesta. La composición, en tanto espacio físico y espacio ideal, proyecta imágenes de prolijidad, limpieza, luminosidad, donde la presentación del producto envasado, con el peso exacto y colocado en una góndola, permite al/a la consumidor/a seleccionar, comparar y "elegir libremente”. Y el súper, entonces, constituye una de las manifestaciones de "lo moderno".

Como mencionara anteriormente, los almacenes son vividos como fuera de tiempo, principalmente por los sectores sociales que "viven la ciudad" con lógicas que excluyen los comercios barriales como ámbitos de aprovisionamiento principal. Éste tipo de experiencias diferenciadas que pude observar, y que podría denominar como experiencias de clase, son factibles de ser captadas a partir del método etnográfico que 
privilegia la óptica de clase (Fonseca, 2005). La vivencia de Silvana, nos resulta ejemplificadora en este sentido: "Pasa que ahora vivo en el centro. $Y$ acá no te hacés de un almacén en particular porque variás mucho de lugares a donde comprar. Si se te cerró uno, vas al otro, vas al Carrefour que está todo el día abierto y hasta tarde”.

En este primer nivel de análisis general sobre los almacenes de barrio, puede ir reconstruyéndose el entramado que constituye esa "esencia". En esta construcción semántica, aparece lo tradicional/moderno, como principal eje estructurador de sentidos. Vincularé entonces los atributos asociados a los almacenes de barrio, con aquellas características que remiten a lo que en la literatura antropológica se definió como sociedad folk (Redfield, 1978 [1932]), revelando cualidades tanto idealizadas y románticas, atribuibles a los pequeños poblados, como la solidaridad, la armonía y la calidez. La sociedad folk así definida, en oposición a la sociedad moderna, es representada por el no cambio, como lo inmutable: "Como te decía, como te contaba, como antes quiero decir. Hay barrios donde la gente se conoce mucho, sigue haciendo lo mismo. Te contaba que todavía sigue el almacén de Pepe, iImaginate!”. En ese "como antes", es representado tanto el almacén, como las personas, incluso algunos barrios. Se observan nuevamente asociaciones semánticas entre el antes/tradicional, el almacén y el barrio, que presentan sus opuestos con el ahora/moderno, el súper y el centro urbano.

El repaso histórico anteriormente realizado, atendiendo a las asociaciones del sentido común en un "orden” evolutivo (pulpería - ramos generales - almacén de barrio - supermercado - hipermercado), permitió ir organizando los diversos sentidos desde donde se proyectan esas imágenes que configuran el almacén, desde la dimensión identitaria en la actualidad (su esencia). La identidad del almacén de barrio es construida a partir de una oposición fundamental, que es la modernidad (el supermercado, la ciudad o lo urbano-metropolitano, lo impersonal, lo frío). Y por contraste, lo que se opone a la modernidad, es lo tradicional. Categoría habitualmente asociada a valores $\operatorname{positivos}^{18}$ como la familia y lo personal, la confianza. Estos sentidos remiten al análisis de la modernidad anti barrial del complejo habitacional en el cual Gravano explica:

\footnotetext{
${ }^{18}$ También se le asocian valores negativos como vimos, como la usura, lo cual entraría en contradicción con la "confianza" y la "familia".
} 
Ya se vio cómo los barrios de hoy, como realidades tangibles e históricas, pertenecen, sin duda, al mundo de la modernidad (urbana, industrial); pero, en gran medida, han sido valorados -dentro mismo de la ideología de la modernidad-, como una muestra paradigmática de un romántico ideal pre-moderno, donde la vida comunitaria de relaciones primarias se valora como auténticamente humana y es considerada decadente en el mundo moderno (Gravano, 2003: 171).

Este análisis constituye un importante aporte para la comprensión del objeto de estudio, en tanto que el almacén de barrio no existe por fuera del mundo moderno. Pero de alguna manera estos comercios son reivindicados como esa muestra romántica ideal pre-moderna. Se les atribuye una esencia, un cuerpo de valores y sentidos propios que lo identifican y lo constituyen en tanto tales, proceso que implica la naturalización y deshistorización del almacén de barrio.

Un análisis global de los registros hasta aquí expuestos, evidencia una clara predominancia de actores sociales cuyas variables de base remiten a sectores de clase media, sumado a las fuentes de proyección de imaginarios mass mediáticos y eruditos. Esta observación nos obliga a pensar en términos de imaginarios hegemónicos que ubican las imágenes de los típicos almacenes de barrio en el pasado, o hacia lo rural, e incluso poseen la capacidad de invocarlas como esencia que perdura en los supermercados céntricos, o como uso vintage o retro (de la categoría "almacén" a secas) para comercios de variados rubros.

Esta característica de "estar fuera de tiempo", complejiza y problematiza la dimensión estrictamente "empírica" del almacén. Se requiere entonces de la construcción de una categoría que permita dar cuenta de "eso que la gente dice" cuando habla del "típico almacén de barrio" o cuando se opina que un supermercado "aún posee" la esencia de un almacén de barrio. Existen entonces determinadas cualidades valorativas que denomino lo almacén del almacén (remitiéndome nuevamente a Gravano en su distinción respecto de lo barrial del barrio), lo que le otorga un estatuto de símbolo. Dichos valores, conforman una red de sentido coherente (naturalizada) para el sentido nativo. Pero las contradicciones sólo se hacen "visibles" en el análisis, aportándonos esos "ojos de buey por donde se hace posible atravesar la opacidad de los símbolos con que se construye la ideología" (Gravano, 2013: 141). 


\section{Lo almacén}

En el ámbito del almacén, que fue seleccionado como "referente empírico", "lo del Alberto", y del barrio en el que se centró esta investigación ${ }^{19}$, al preguntar por el almacén de barrio, éste era referenciado inmediatamente con "el almacén de la esquina", "lo del Alberto", o bien "Lo de la Mary", el almacén de la "otra cuadra". Una de las situaciones de campo fue particularmente ejemplificadora en este sentido. Luego de haber pactado una visita a lo de Marta, una vecina del almacén de "lo del Alberto", al llegar a su casa, con el mate ${ }^{20}$ preparado y unos bizcochos me dice: "Bueno, ¿qué queré' que te cuente del Alberto?"

Pero si bien las identificaciones con comercios "del pasado" o "rurales" en éstos contextos no se manifestaron, sí encontré representaciones ligadas a esencias y tipicidades. El almacén de barrio en tanto espacio vivido (Gravano, 2003), e incluso apropiado, es depositario de atributos que remiten a tipos de vínculos: el almacenero que es cura, psicólogo, amigo. La relación cálida en oposición a lo frío de los supermercados, la existencia de lo familiar, comunitario y popular, donde la confianza se constituye como el valor fundamental, reivindicado por los mismos actores sociales.

Inés: ¿Y con los clientes la relación cómo es?

Alberto (Almacenero): Es buena, es tipo familiar, es familiar la relación.

Noelia (almacenera, esposa de Alberto): Si, con los clientes, sí... [Lo dice a la par de Alberto]

I: Claro, comparten también la vecindad...

A: Si... y vienen, hablan, cuentan...

$\mathrm{N}$ : ¡Sos el cura! [Le dice Noelia a Alberto. Hay clientes que se ríen]

A: Contamos cosas.

I: ¿Sos el cura?

A: El cura también...

$\mathrm{N}$ : Con los clientes viejos.

A: Siempre son gente vieja la que viene.

\footnotetext{
${ }^{19}$ Como características principales que "distinguen" al barrio en el que realicé la investigación, podemos mencionar la predominancia de casas de autoconstrucción, aunque actualmente comiencen a marcar presencia empresas constructoras grandes de la ciudad; la presencia de una colectividad boliviana organizada, de residencias estudiantiles y de una playa de estacionamiento de camiones. Esta presencia evidencia la cercanía del barrio a una de las vías de acceso a la ciudad que la conecta con el sector industrial y con las canteras.

${ }^{20}$ Tipo de infusión, habitual en Argentina, Uruguay y Paraguay.
} 
En tanto alguno de estos comercios en el barrio no manifestara poseer las tipicidades que constituyen lo almacén de un almacén, por ejemplo, que no dé fiado, o que "sea atendido con la frialdad de un supermercado", el carácter de "típico almacén de barrio" era objeto de debate entre los vecinos.

Los almacenes son considerados, por contraste con los comercios "modernos", como "ámbitos familiares". Esta caracterización podría desprenderse en principio por la organización del trabajo, de tipo familiar. Pero además, los almacenes son ámbitos descritos como "familiares" debido a una forma de involucramiento particular entre cliente y comerciante (quienes además pueden ser amigos/as, parientes o vecinas/os). Expresiones como "somos una gran familia" o "acá la relación es de tipo familiar", son ejemplos contundentes del modo en que se significan las relaciones que se establecen.

Al indagar sobre por qué se considera que es familiar la relación, surgen explicaciones ligadas al conocimiento mutuo y la confianza: "porque nos conocemos mucho, sabemos todo lo que le pasa al cliente”. Lo familiar, aparece también vinculado a las relaciones de amistad y confianza: el conocimiento mutuo, "saber qué le pasa al otro", ser el "confesionario", "el cura del barrio". "El almacén de barrio es un lugar de confianza. Es un lugar en el que las personas pueden contar con alguien que los escuche", manifestó el almacenero, a modo de definición, en una de las entrevistas. Estas representaciones sobre los tipos de lazos sociales que se establecen en los almacenes, entran en conflicto (en los discursos) cuando se hace explícito otro tipo de lazo social, culturalmente "opuesto" al "familiar": el "comercial" o el de "los negocios". Muy habitualmente solemos oír frases como "más que cliente es un amigo", pero también manifestaciones como:

J: Nosotros, siempre tratamos de que lo que hace uno le sirva al otro. Porque por ahí uno lleva productos que a él no le sirven y no vas a insistir en vendérselo... por el compromiso de que tenemos una amistad, pero... ¡más allá de la amistad está el negocio! (Jorge, proveedor del almacén del Alberto).

Estas contradicciones entre las representaciones de lo comercial y lo familiar, son indicios para el análisis. Retomando la hipótesis planteada en los inicios de este trabajo, en la que establecí una relación entre la necesidad estructural del fiado para la re-producción de los sectores populares y los almacenes de barrio como el sistema sociocultural que lo posibilita, el conflicto que se pone de manifiesto aquí es entre el aprovisionamiento humano y el sistema social que lo organiza en el capitalismo. 
Denomino entonces "lo almacén" al sistema de valores que se manifiesta en el conjunto de prácticas y representaciones, que son las tipicidades. Estas tipicidades, en términos generales serían: lo familiar, el chusmerío, el nombre, el fiado, la yapa, entre otras. La construcción de esta categoría analítica pondera a los almacenes en su dimensión identitaria y consiguientemente preguntarnos por ¿qué es lo que se naturaliza y qué es lo que se "muestra" cuando se invoca al almacén de barrio?

\section{"Con esencia de Almacén de Barrio"}

Preguntarnos por los imaginarios sociales en torno a la noción nativa referida a los almacenes de barrio en una ciudad media, requiere de algunas precisiones conceptuales. En principio problematizar el carácter "medio" o "intermedio" de las ciudades, definido sobre la base de las consideraciones de tamaño físico y talla demográfica (entre cincuenta mil y un millón de habitantes) y por su rango en la escala entre las metrópolis y los poblados rurales. Incluso las perspectivas que introducen en sus análisis variables de tipo cualitativas, tomando en consideración aspectos identitarios, simbólicos o culturales, suponen a las ciudades "como meros espacios físicos y como variables independientes de la estructura socioeconómica y del sistema capitalista” (Boggi y Galván, 2015: 37).

Estas problematizaciones elaboradas por sendas investigaciones en Antropología Urbana (Gravano, Silva, Boggi, 2016; Gravano 2005), apuntan a la construcción del concepto de ciudades medias bajo un paradigma histórica-estructural y dialéctico. Pero fundamentalmente a la producción de teorías a partir de interpelar las prácticas y los sentidos y en definitiva los modos en que los actores sociales vivencian la ciudad, cómo la piensan, la sufren, la disfrutan, la invocan. Se apunta a poder comprender el modo en que los almacenes de barrio son vividos y representados en una ciudad media como Olavarría, comprender las reivindicaciones en torno a su esencia que, en los imaginarios hegemónicos, se manifiesta como "pérdida" y sobre todo intentar explicar qué es lo que se muestra y oculta con estas evocaciones.

A partir de estas propuestas de indagación, incorporaré una noción que es trabajada como hipótesis en el marco del proyecto de investigación del PROINCOMSCI. Me refiero a la hipótesis de metropolismo, que postula un modelo hegemónico de concepción de lo urbano como metropolitano, tanto teórica como de 
sentido común y de los modelos de gestión político-institucional. Esta hipótesis afirma "que el modelo de dependencia del imaginario hegemónico metropolitano [...] incide en la especificidad del funcionamiento de los sistemas institucionales y el cumplimiento de sus propósitos específicos" (Gravano, 2016: 86). En este sentido, se puede esbozar una interpretación de aquellas evocaciones, tanto positivas como negativas de los almacenes de barrio, teniendo en consideración este modelo metropolitano de ciudad, que "se proyectaría hacia la ciudad media" a través de diversos dispositivos, como por ejemplo el mass mediático, “construyendo isomórficos mapas ideológicos-simbólicos" (Idem: 87).

Uno de los interrogantes que se vienen planteando a lo largo de este trabajo tiene que ver con qué es lo que se muestra/oculta cuando se invocan los almacenes de barrio, como reivindicación. Propuse que esta reivindicación de los "almacenes de barrio" bajo el paradigma de la modernidad urbana, se manifiesta a partir de la reconversión de los formatos comerciales "tradicionales" en "modernos". Pero esta verificación requiere comprender qué es lo que se vivencia como "crisis", o como momento de ruptura. El tratamiento tanto de los medios de comunicación, cuanto de los textos académicos vinculados al análisis económico y geográfico, refuerzan este posicionamiento ideológico de los comercios "tradicionales" frente al avance de la modernidad comercial, construyendo una idea de "crisis" del sector.

Economistas como José Luis Coraggio y Rubén Cesar, para fines de la década de 1990, sostenían que:

\begin{abstract}
El impacto urbano de esta reorganización del comercio no es menor: el comercio tradicional, pequeño e incluso bajo la forma de cadenas especializadas, sufre la quiebra de los comercios peor colocados por su localización o su ineficiencia, con la consiguiente pérdida de empleos y en ocasiones la desvalorización de sus propiedades en zonas que constituían centros comerciales de la ciudad. Esto a su vez afecta indirectamente a las redes de abastecimiento de esos comercios, muchas de cuyas PYMES no pueden cumplir con los requerimientos de las grandes cadenas en lo referente a calidad, precio, cantidad y continuidad dentro de un régimen just in time (Coraggio y Cesar, 1999: 9).
\end{abstract}

Estos análisis se correspondían además con el propio análisis de los actores del sector comerciante, quienes eran partícipes de la imposición del nuevo formato comercial de grandes superficies y frente a su imposibilidad de generar condiciones de competitividad, en un mercado sin regulaciones estatales: 
Es importante señalar que el $83 \%$ de los comerciantes pequeños reconoce que la instalación de hipermercados tiene un efecto negativo sobre sus comercios. Más aún: el $62,7 \%$ opina que la situación empeorará y el $29,5 \%$ que se mantendrá igual. Esto no surge de una interpretación subjetiva de estos comerciantes, sino que está basada en datos de la realidad de estos comercios, que ven cómo sus ventas se reducen mientras que la participación de los hipermercados en el mercado minorista aumenta (Coraggio y Cesar, 1999: 9).

Mientras que Di Nucci y Lan, para la misma época, realizan un análisis similar, donde muestran una caída a partir de la década de 1990 en la participación de los comercios tradicionales en la estructura comercial local:

Este crecimiento relativo de los supermercados en las ventas alimentarias, se logra a expensas de los almacenes, de las ferias y mercados; así aunque en los '80, continuaba existiendo una estructura comercial con gran importancia del comercio tradicional, comienza a observarse una importante caída en su participación, de 56,4\% en 1984 a 43,8\% en 1991 (Di Nucci y Lan, 2008: 187).

La llegada del primer supermercado (Casa Tía) a Olavarría en 1995, sitúa conflictivamente a la ciudad en "el camino hacia la modernidad comercial". Su construcción no sólo será el reflejo de un proceso más profundo y estructural a nivel nacional $^{21}$ e incluso mundial, vinculado a políticas neoliberales, y a la globalización del comercio en general. Casa Tía, como representante concreto de "esa modernidad", es instalado en la ciudad proponiendo nuevas estrategias de venta, como el aprovisionamiento ligado al paseo, el autoservicio, la góndola, la ilusión de flujo y rapidez a partir de los amplios pasillos y la “caja rápida".

Vos sabés que, cuando llegó Casa Tía, por los noventa, noventa y pico, me acuerdo que al principio fue un escándalo porque, donde está ahora, que es Carrefour, ahí había un edificio donde funcionaban los talleres protegidos. Y era además un edificio histórico, si mal no recuerdo. Y... y bueno. La gente al principio, nada, todos indignados, que $<$ ¡cómo van a hacer eso con el edificio! $>$ y qué se yo... Cuestión que ni bien se abre, todos o la mayoría de los que se quejaban, vos los veías con las bolsas contentos salir del súper (Mujer, 38 años, empleada pública).

La demolición del edificio histórico, constituiría una objetivación concreta del proceso de reconversión urbana (Harvey, 2012). Harvey propone a la urbanización como desempeñando un papel activo (en términos de función) "en la absorción del

\footnotetext{
${ }^{21}$ La transformación en los modos de comercialización (el autoservicio ligado al supermercadismo) se produce en Argentina a partir de la década de 1950.
} 
producto excedente que los capitales producen continuamente en la búsqueda de plusvalor" (Harvey, 2012: 24). En este sentido las re-estructuraciones, en términos de infraestructura urbana, que el autor denomina como "destrucciones creativas", serían comprendidas en el contexto de estas necesidades de búsqueda de absorción de excedentes. Éstas dinámicas de destrucciones creativas, que van re-inventando las ciudades, los modos de uso de los distintos espacios y las significaciones en torno a éstos, culminan con la desposesión de los derechos a la ciudad por parte de las masas urbanas (Idem: 45).

La reconversión de aquel espacio y lo "creativo" de esa destrucción, es lo que posicionaría imaginariamente a Olavarría como una ciudad moderna, en sintonía con el modelo metropolitano de lo urbano, en tanto sería "un paso importante para que Olavarría se convierta en un polo comercial de la región", según la mirada del poder ejecutivo municipal de aquellos años, Helios Eseverri (Nota periodística redactada por Silvana Melo en el medio gráfico local El Popular el 8 de Febrero de 2015). Pero la llegada del súper implicará además nuevas formas de vivenciar el comercio y la ciudad, posicionando imaginariamente a los almacenes en el polo de "lo tradicional", "lo pequeño", "lo local” y "barrial", frente a "lo moderno", "lo hiper/súper" y "extranjero/multinacional” de las grandes superficies.

Con la esencia del almacén de barrio

17 de Septiembre de 2012

EDICIÓN IMPRESA // LA CIUDAD

DIA DEL ALMACENERO. Julio De Felice, más de veinte años con Minimercado Lamadrid

De Felice y una tradición que comenzó su abuelo.

Julio De Felice (50), propietario de Minimercado Lamadrid en pleno corazón del barrio San Vicente Sur, hace ya más de dos décadas que está allí instalado...Al principio se trabajaba como almacén de barrio. Todavía no estaba Casa Tía, que fue el primer gran supermercado que se instaló en Olavarría y ahí comenzaron a cambiar los estilos para comprar la mercadería. Pero antes era diferente... yo alcancé a trabajar con la libreta donde le anotábamos al cliente lo que iba llevando fiado. E inclusive en algunos almacenes de la periferia siguen haciéndolo.

Y si bien la comercialización ha cambiado, en el almacén de barrio sigue estando al frente del mismo el que además de vender hace de amigo, psicólogo o médico... no existe esa relación fría que está en los grandes supermercados. Y si bien algo de aquella costumbre se ha perdido, con los viejos clientes eso se mantiene intacto. E inclusive tengo cuenta corriente con los más conocidos, con los más antiguos", recuerda De Felice (Diario El Popular-On Line- de la Ciudad de Olavarría17/09/2014). 
Como puede observarse en esta nota, llamativamente desde la redacción del periódico local, se seleccionó un supermercado "céntrico" para homenajear a "los almaceneros" en su día. Se expresa la idea de "progreso" en sentido evolutivo positivo, en tanto que De Felice reconoce que "antes trabajaba como almacén de barrio”, lo que evidencia el reconocimiento de un proceso de reconversión del formato y de los estilos de venta y su valoración del mismo. Y si bien menciona prácticas (típicas) como formando parte del pasado (el fiado y la libreta,) y que incluso "algunos almacenes de la periferia siguen haciéndolo”, finalmente reconoce que él mismo mantiene algunas cuentas corrientes con los clientes “con los más conocidos, con los más antiguos”. El análisis de este artículo es particularmente rico en tanto que nos permite evidenciar dos cuestiones. Por un lado la necesidad estructural del fiado. Más que como práctica "en vías de desaparecer", pude observar y registrar que el sistema de crédito informal constituye un sistema que posibilita el acceso a bienes necesarios para la reproducción a un amplio sector de la sociedad, concretamente a los sectores populares. En este sentido, la confianza, la amistad, el conocerse de toda la vida, constituyen variables que se ponen en juego en la construcción de sujetos fiables/no fiables. La existencia de estas construcciones simbólicas (lo almacén y lo fiable) son interpretadas como elaboraciones simbólicas de las contradicciones estructurales: el fiado como necesidad para la reproducción (que permite el acceso a los consumos colectivos) y la imposibilidad por parte del almacenero o la almacenera de "darle fiado a todo el mundo".

Por otro lado este recorte periodístico expone la necesidad de invocar lo barrial como un valor "que incluso" se encuentra (como esencia) en el "súper del centro". Propongo que la categoría de lo fiable, se ancla al mismo tiempo en "el ser de barrio": le fío porque es de barrio. El recorrido hasta aquí realizado nos permite pensar en que no se le da fiado únicamente por "vivir en el barrio". De la misma manera, no es un almacén de barrio por el hecho de estar físicamente en el barrio. En este sentido escribe Gravano al definir lo barrial como producción ideológica:

En concreto, se haya nacido o no, vivido o no en un barrio, existe un horizonte simbólico ideológico urbanamente socializado -en forma diferencial- acerca de los que significa ser de barrio, como conjunto de cualidades referenciables y establecidas para valorar comportamientos, representaciones y prácticas (Gravano, 2003: 267). 


\section{Conclusiones}

Las permanentes re-formas, en clave de lo que Harvey denomina "destrucciones creativas", posicionan a la ciudad al servicio de la reproducción del capital. En este proceso creativo, de producción de lo urbano, la ciudad ofrece un sistema de consumos colectivos para la reproducción de la fuerza de trabajo, al tiempo que estructura un acceso diferencial a los mismos. El imaginario hegemónico metropolitano, como imagen y modelo de ciudad y de lo urbano, integra esta contradicción. El proceso de esencialización y naturalización del almacén de barrio, en tanto sistema de aprovisionamiento, debe comprenderse en el contexto de lucha por el acceso a los consumos colectivos en la ciudad capitalista. El abordaje antropológico de este sistema de aprovisionamiento, "el almacén", nos permite desnaturalizar este fenómeno y comprenderlo como una construcción social, simbólica y material al mismo tiempo: lo almacén. Esta construcción legitima una forma de organización social de aprovisionamiento que garantiza y reproduce la apropiación desigual del excedente urbano.

Enfaticé en la distinción de la construcción de lo almacén respecto del típico almacén de barrio, en tanto que ésta última categoría responde a una construcción del imaginario social hegemónico en torno a los almacenes, y que integra en su identidad, de modos no armónicos, aquellas imágenes superpuestas que Gravano denomina palimpsesto.

Uno de los interrogantes que planteo en este trabajo consiste en comprender qué es lo que se muestra/oculta cuando se invocan los almacenes de barrio, como reivindicación. Sostuve como hipótesis que esta reivindicación, bajo el paradigma de la modernidad urbana, se manifiesta a partir de la reconversión de los formatos comerciales "tradicionales" en "modernos". El trabajo etnográfico me permitió reconstruir el modo en que los actores sociales que no dependen de las lógicas informales para su reproducción como clase, invocan valores positivos de lo almacén y lo barrial (lo familiar, personal, cálido, sencillo) naturalizados como esencia y referenciados en sectores que poseen lógicas de comercialización "modernas", es decir, donde las formas de crédito informal están casi ausentes. Se recuperan esos valores al tiempo que se estructura una mayor desigualdad al acceso a los consumos colectivos (que la ciudad capitalista ofrece como valor de uso para su reproducción). La 
apropiación simbólica de estos valores, posiciona imaginariamente a los pequeños comercios de los barrios y sus lógicas de aprovisionamiento "periféricas", en el polo de lo tradicional y de lo atrasado. El barrio adquiere nuevamente, en esta distribución desigual de los valores, su función naturalizadora de la desigualdad social.

\section{Referencias}

ABLIN, Amalie. El supermercadismo argentino. Alimentos Argentinos. Min-Agri. Mes de julio. 2012. Recuperado el 12 de Enero de 2014. En: www.alimentosargentinos.gob.ar.

BANDIERI, Susana. "Bandoleros, almaceneros y acopiadores. Familias comercio y poder en el Territorio Nacional del Neuquén". En: XVII Jornadas de Historia Económica, Tucumán, 2000.

BIALET MASSÉ, Juan. Informe sobre el Estado de las Clases Obreras Argentinas. Volumen I. La Plata, Ministerio de Trabajo de la provincia de Buenos Aires. Vol I, 231 páginas, 2010.

BOGGI, Silvia y Galván, N. Ciudad media, ciudad intermedia: ¿Ni chicha ni limonada? En: Gravano, Ariel; Silva. A. y Boggi, S (Editores). Ciudades vividas. Ciudad Autónoma de Buenos Aires, Café de las Ciudades, 2015.

CASTELLS, Manuel. La cuestión urbana. Madrid, Siglo XXI, 1974.

CASTELLS, Manuel y Portes, A. "El mundo sumergido: los orígenes, la dinámica y los efectos de la economía informal". En: Portes, A. (Ed). La economía informal en los países desarrollados y en los menos avanzados. Buenos Aires, Planeta, 1986.

CORAGGIO, José. L. y César, R. "¿Qué debe hacer el gobierno local ante los grandes emprendimientos en el comercio minorista?". En: EURE, Vol.25 Nro.75. Septiembre, Santiago. 1999.

DEL ÁGUILA, María Inés “'Le fío porque es de barrio', un estudio antropológico sobre la complejidad material y simbólica de los intercambios sociales en los almacenes de barrio" (tesis de grado) Universidad del Centro de la Provincia de Buenos Aires, Facultad de Ciencias Sociales, Carrera de Antropología Social.

DI NUCCI, Josefina. y Lan, D. "Cambios en la distribución minorista de alimentos y bebidas en Argentina 2001-2003: Hacia nuevas horizontalidades territoriales". En: Geograficando, No 3(3), pp. 129-149. 2007.

DI NUCCI, Josefina y Lan, D. "Globalización y modernización del comercio minorista argentino en la década de los noventa”. En: Huellas, Nº12, pp. 176-197. 2008.

DUART, Diana. "El crédito como relación social: algunas consideraciones sobre los vínculos comerciales en el área de la frontera bonaerense siglo XIX". En: Jornadas "Problemas y debates del temprano siglo XIX", Universidad Nacional de Mar del Plata. 2005.

GRAVANO, A. (Comp.). Imaginarios sociales de la ciudad media. Emblemas, fragmentaciones y otredades urbanas. Estudios de Antropología Urbana. Tandil, Red de Editoriales de Universidades Nacionales, 2005.

Antropología de lo barrial. Estudios sobre producción simbólica de la vida urbana. Buenos Aires, Ed. Espacio, 2003.

Antropología de lo urbano. Buenos Aires, Café de las ciudades (II

edición corregida y aumentada), 2015. 
Antropología de lo urbano. Tandil, Universidad Nacional del Centro de la Provincia de Buenos Aires, 2013.

El barrio en la teoría social. Buenos Aires, Ed. Espacio, 2005.

Hacia un marco teórico sobre el concepto de barrio. En: Gravano, A. (comp): Miradas urbanas- visiones barriales. pp 255-280. Montevideo, Nordan, 1995.

Tres Hipótesis sobre la relación entre sistema urbano e imaginarios de las ciudades medias. En: Gravano, Ariel; Silva. A. y Boggi, S (Editores). Ciudades vividas. Ciudad Autónoma de Buenos Aires, Café de las Ciudades, 2015.

GRAVANO, Ariel; SILVA. Ana y Boggi, Silvia (Editores). Ciudades vividas. Ciudad Autónoma de Buenos Aires, Café de las Ciudades, 2015.

GUBER, Rosana. La etnografía: método, campo y reflexividad. Buenos Aires, Siglo XXI, 2011.

GUBER, Rosana. Barrio sí, villa también. Buenos Aires, Centro Editor de América Latina, 1991.

HAMMERSLEY, Martyn y Atkinson, P. Etnografía, métodos de investigación. Barcelona, Paidós, 1994.

HARVEY, David. Ciudades rebeldes. Del derecho de la ciudad a la revolución urbana. Madrid, Akal, 2012.

HARVEY, David. Urbanismo y desigualdad social. Madrid, Siglo XXI, 1977.

LYNCH, Kevyn. La buena forma de la ciudad. Barcelona, G. Gili, 1985.

LYNCH, Kevyn. La imagen de la ciudad. Buenos Aires, Infinito, 1966.

LLUCH, Andrea. "Tengo que hacer las veces de médico, comisario, comerciante, defensor de oficio. Repensando a los comercios rurales de la pampa argentina. 19001930”. Anuario del CEH, No2-3, pp. 135-159. 2002-2003.

LLUCH, Andrea. "Comercio y crédito agrario. Un estudio de caso sobre las prácticas y lógicas crediticias de comerciantes de campaña a comienzos del siglo XX en La Pampa”. En: Bol. Inst. Hist. Argent. Am. Dr. Emilio Ravignani, Núm.29, Enero/Junio, Buenos Aires, 2006.

REDFIELD, Robert. 1978. La sociedad folk. En: Rocca \& Magrassi: Introducción al Folklore. Buenos Aires, Centro Editor de América Latina, 1978.

ROCKWELL, Elsie. 2009. La experiencia etnográfica: Historia y cultura en los procesos educativos. Paidós. Buenos Aires.

SCOBIE, James. Revolución en las Pampas: Historia social del trigo argentino: 18601910. Buenos Aires, Solar/Hachette, 1968.

SCHMIT, Roberto. "Intercambios mercantiles y medios de pagos", ponencia presentada en Seminario la historia económica hoy: balances y perspectivas. Buenos Aires, AAHEAsociación Argentina de Historia Económica, 2005.

SILVA, Ana y Boggi, S. Estudios sobre imaginarios de ciudades medias. En: Gravano, Ariel; Silva. A. y Boggi, S (Editores). Ciudades vividas. Ciudad Autónoma de Buenos Aires, Café de las Ciudades, 2015.

SINGER, Paul. Economía política de la urbanización. México, Siglo XXI, 1981. 


\section{Fuentes secundarias}

Diccionario Enciclopédico "Nuevo Espasa Ilustrado 2001”. Espasa Calpe. España.

Código de Comercio de la República Argentina.(Vigencia 1862 hasta 1 de agosto de 2015). Recuperado el 22 de Mayo de 2012.

http://servicios.infoleg.gob.ar/infolegInternet/anexos/105000-

109999/109500/texact.htm

Con la esencia del almacén de barrio. Diario El Popular de Olavarría. Recuperado el 17 de Septiembre de 2012. 6:20pm.

http://www.elpopular.com.ar/eimpresa.html?n=143495

INDEC, República Argentina, 2010, 2012

http://www.indec.gov.ar/bases-de-datos.asp

http://www.indec.gov.ar/nivel4_default.asp?id_tema_1=2\&id_tema_2=41\&id_tema_3= 135.

Federación Argentina de Empleados de Comercio y Servicios (FAECyS)

http://www.faecys.org.ar/

Federación de Autoservicistas, Almaceneros, Alimentarios y Afines de la Provincia de Buenos Aires (FABA)

http://www.faba-minoristas.org.ar/ley_12573.html

http://www.faba-minoristas.org.ar/mundo_almacenero/mundo274.pdf

Ley de grandes superficies 12.573 (2001)

http://www.gob.gba.gov.ar/legislacion/legislacion/l-12573.html

Minoristas promueven la regulación de la actividad en los hipermercados. Diario el

Popular 22/11/2011

http://www.elpopular.com.ar/eimpresa/120311/minoristas-promueven-mayor-

regulacion-de-la-actividad-en-los-hipermercados.

TimeLine/ Facebook: "Los fabulosos setenta". Recuperado el 15 de Abril de 2016.

https://www.facebook.com/LosFabulososSetenta/photos/a.267042840077509.58746.26

6975113417615/718260461622409/.

Recebido em: 21/09/2017.

Aprovado em: 15/11/2017. 